\title{
Gyomfajok fémakkumulációjának vizsgálata szennyezett területen
}

\author{
Tőzsér Dávid \\ Debreceni Egyetem, Ökológiai Tanszék \\ 4032 Debrecen, Egyetem tér 1. \\ e-mail:tozser.david@windowslive.com
}

\begin{abstract}
Összefoglaló: A növényzetnek fontos szerepe van a szennyezett talajok kezelésében. Munkánk során $\mathrm{Cr}, \mathrm{Cu}, \mathrm{Ni}, \mathrm{Pb}, \mathrm{Sr}$ és $\mathrm{Zn}$ fémekkel közepesen és erősen szennyezett területeken fehér libatop (Chenopodium album L.) és kaporlevelü ebszékfü (Tripleurospermum inodorum (L.) Sch. Bip.) egyedek $\mathrm{Al}, \mathrm{Ba}, \mathrm{Ca}, \mathrm{Cr}, \mathrm{Cu}, \mathrm{Fe}, \mathrm{K}, \mathrm{Mg}, \mathrm{Mn}, \mathrm{Na}, \mathrm{Ni}, \mathrm{Pb}, \mathrm{Sr}$ és Zn koncentrációját vizsgáltuk a gyökerekben, szárban és levelekben. Tanulmányoztuk továbbá a talajminták és az egyes növényi szervek fémkoncentrációja közötti korrelációt. Megállapítottuk, hogy mindkét faj fémfelvételi képessége mérsékelt volt. A növényi szervek közül a legnagyobb $\mathrm{Ca}, \mathrm{K}, \mathrm{Mg}, \mathrm{Mn}, \mathrm{Sr}$ és $\mathrm{Zn}$ koncentrációt a levelekben találtuk. Emellett korrelációt mutattunk ki a talajok és a növények $\mathrm{Al}, \mathrm{Ca}, \mathrm{Cr} \mathrm{Cu}, \mathrm{Fe}$, $\mathrm{Mg}, \mathrm{Ni}, \mathrm{Pb}$ és Sr koncentrációja között. Eredményeink alapján megállapítottuk, hogy a fehér libatop és a kaporlevelű ebszékfü alkalmasak lehetnek a fémszennyezés csökkentésére. Ez elsősorban föld feletti növényi szerveik fémakkumulációja révén valósulhat meg.
\end{abstract}

Kulcsszavak: fém, bioakkumuláció, Chenopodium album, Tripleurospermum inodorum, gyomfajok, növényi szervek

\section{Bevezetés}

A nem megfelelő talajhasználat okozta szennyeződések elkerülése és csökkentése világszintủ kihívást jelent (Hoefer et al. 2015). A károsodások egyik fő megnyilvánulási formája a talajok fizikai és kémiai összetételében történő változás (Ishikawa et al. 2014). A kémiai elemek háttér-koncentrációtól való jelentős eltérése toxikus hatással lehet a talajjal érintkező élőlényekre, mely végső soron akár az élőlények pusztulását is eredményezheti (Mahar et al. 2016). Bizonyos növényfajok képesek a szennyező anyagokat növényi szerveikben a nélkül felhalmozni, hogy életfolyamataikban vagy egészségi állapotukban számottevő hanyatlás következne be. Erre az előnyös növényi tulajdonságra alapozva a szennyező anyagokkal (pl. fémekkel) terhelt talajok alternatív, környezetkímélő módszerekkel történő megtisztításának módja lehet a fitoremediáció (Vangronsveld et al. 
2009), ezen belül a szennyező anyagok növényi felvételén alapuló fitoextrakció (Zimmer et al. 2009).

A fitoextrakciós folyamat során specifikus növényi jellemzők érvényesülnek, így a remediációban az ezek birtokában lévő fajok a legsikeresebbek. Ezek közé tartozik a nagymértékủ fémtolerancia, gyors növekedés (nagy biomassza-hozam) és kiterjedt gyökérzóna, mely vonások elsősorban fás szárú növényfajokra jellemzőek (Kacálková et al. 2015, Tőzsér et al. 2017). Ezek mellett azonban az utóbbi évek kutatásai nagy hangsúlyt fektettek a természetes vegetációban tömegesen előforduló lágy szárú fajok fémakkumulációjának vizsgálatára (Bandiera et al. 2016).

Fémfelvételi potenciáljuk szempontjából a Chenopodiaceae család fajai, közülük is főként a jó stressztürő képességgel rendelkező fehér libatop (Chenopodium album L.) számos kutatás tárgyát képezték (Hu et al. 2012). Korábbi tanulmányukban Parisien et al. (2015) igazolták, hogy a faj a talajok kis és nagy fokú fémszennyezettsége mellett egyaránt képes volt a $\mathrm{Fe}, \mathrm{Mn}, \mathrm{Cd}, \mathrm{Cr}, \mathrm{Cu}, \mathrm{Ni}, \mathrm{Pb}$ és Zn jelentős mértékủ akkumulációjára. Gupta \& Sinha (2007) a felsorolt fémek esetében ugyanerre a megállapításra jutottak. Bhargava et al. (2008) a Fe, Cd és $\mathrm{Cu}$ esetében mutattak ki jelentős akkumulációt a fehér libatopban, így a szerzők a faj remediációs alkalmazását egyértelmúen javasolták.

A kaporlevelü ebszékfü (Tripleurospermum inodorum (L.) Sch. Bip.) egynyári, bizonyos körülmények mellett évelő faj (Kay 1994). Korábban a faj gyökereinek Cu-adszorpciós képességét Dousset et al. (2001) vizsgálták. Ezen kívül eddig nem készült olyan tanulmány, mely átfogóan vizsgálta volna a kaporlevelü ebszékfü fémfelvételi képességét. Ezzel ellentétben számos publikáció készült a rokon Matricaria fajokról, legnagyobb számban az igazoltan jó akkumuláló orvosi székfüröl (Matricaria chamomilla vagy Matricaria recutita) (Armendaríz et al. 2014, Stanojkovic-Sebic et al. 2015). Érdemes megjegyezni, hogy a Tripleurospermum és Matricaria fajok taxonómiai besorolása igen vitatott (Applequist 2002). Példaként a Tripleurospermum inodorum fajra gyakran Matricaria inodora megnevezéssel hivatkoznak (Samatadze et al. 2014).

Munkánk során arra kerestük a választ, hogy a két gyomfaj milyen mértékben alkalmas fémekkel mérsékelten és erősen terhelt talajok szennyezettségének csökkentésére. Hipotézisünk szerint mindkét faj kedvező fémakkumulációs potenciállal rendelkezik. Hipotézisünk volt továbbá, hogy különbség jelentkezik a fajok növényi szerveinek fémkoncentrációja között; a koncentrációk maximumát a fehér libatop leveleiben, és a kaporlevelü ebszékfü gyökereiben feltételeztük. 


\section{Módszerek}

Vizsgálati területként a Debrecen délnyugati határában elhelyezkedő Lovász-zugi tórendszert választottuk $\left(47^{\circ} 29^{\prime} 000^{\prime \prime}\right.$ É, $\left.21^{\circ} 35^{\prime} 738^{\prime \prime} \mathrm{K}\right)$. A 26 ha kiterjedésű terület az 1930-as évektől egészen az ezredfordulóig kulcsszerepet töltött be a város kommunális szennyvíztisztítási folyamatában, majd rekultivációs munkálatok színtere lett (Tözsér et al. 2017b).

A növényi mintavételt a vizsgált terület három eltérö mértékben szennyezett (északi - mérsékelten szennyezett 1-es; középső - erősen szennyezett 2-es; déli - mérsékelten szennyezett 3-as) részéröl 2015 szeptemberében végeztük el. A fehér libatop és a kaporlevelü ebszékfü esetében is 5-5 db egyedet gyüjtöttünk, a korábban végzett talajtani vizsgáltatok 10 méteres sugarú körzetéből (Tőzsér et al. 2018). A minták laboratóriumi feldolgozását Simon et al. (2011, 2012, 2014, 2016) munkáiban közölt módszerek alapján végeztünk. Az alábbi fémek koncentrációja került meghatározásra mikrohullámú plazma atomemissziós spektrométer (MP-AES) készülékkel: Al, Ba, Ca, Cd, Cr, Cu, Fe, K, Mg, Mn, Na, Ni, Pb, Sr és Zn.

A statisztikai analízis során számításainkat a fémkoncentrációk természetes alapú logaritmusával (ln) végeztük. A varianciák homogenitását Levene-teszttel vizsgáltuk. A gyomfajok, a különböző szennyezettségü területek és a növényi szervek közötti fémkoncentrációk közötti különbségek megállapítására általános lineáris modellen alapuló variancia-analízist (GLM ANOVA) használtunk.

\section{Eredmények}

A fehér libatop növényi szerveinek fökomponens-analízissel (PCA) történő vizsgálata során azt tapasztaltuk, hogy a gyökerek, szár és levelek fémkoncentrációja az egyes megvizsgált területrészek között jelentősen különbözött (1. ábra). A kaporlevelü ebszékfü főkomponens-analízise azt mutatta, hogy az egyedek leveleinek fémkoncentrációja jelentősen eltért a gyökerek és a szár fémkoncentrációjától (2. ábra).

A GLM-analízis eredményei alapján a két faj között, a növényi szervek között és a vizsgált területek között is szignifikáns $(\mathrm{p}<0,05)$ különbségeket tapasztaltunk (1. és 2. táblázat). A K és Mg a fehér libatop, míg az Al, Fe, Mn és Na a kaporlevelü ebszékfü egyedekben volt jelen szignifikánsan nagyobb koncentrációban. A növényi szervek között az Al, Ca, Fe, K, Mg, Mn, Na, Ba, Cr, Cu, Ni, Pb, Sr és Zn esetében volt szignifikáns különbség. Az egyes területrészek között pedig 


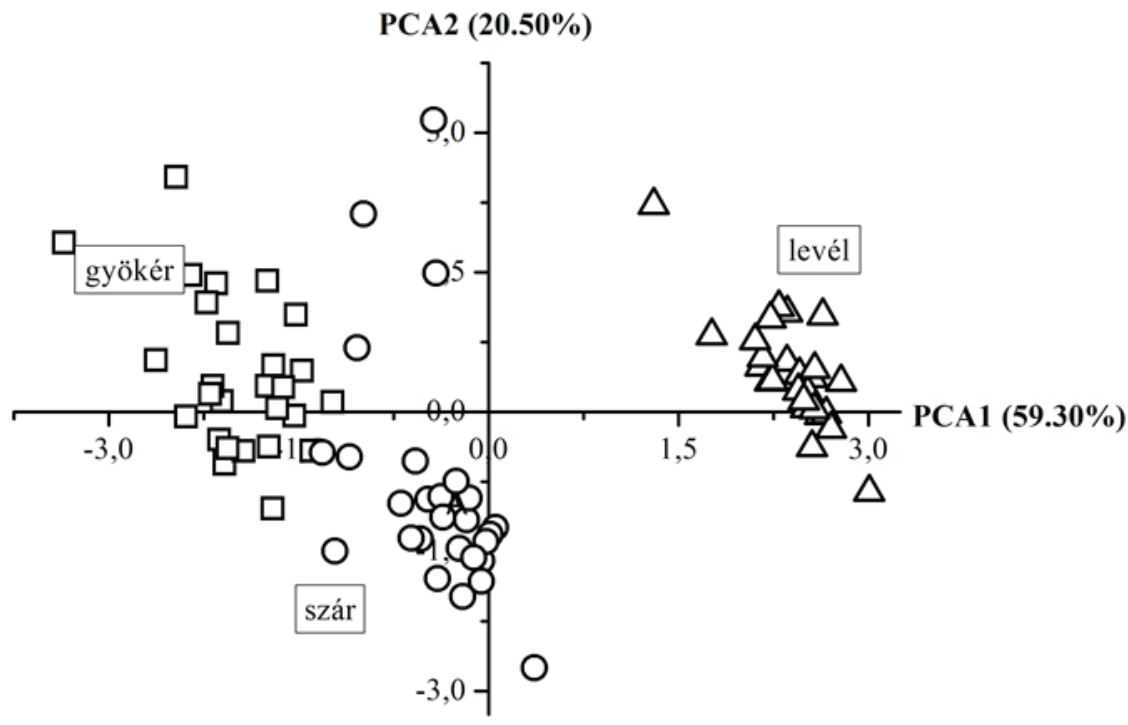

1. ábra: A fehér libatop egyedek növényi szerveiben mért elemkoncentrációk ( $\left.\mathrm{mg} \mathrm{kg}^{-1}\right)$ fökomponens-analízise. Jelölések: négyszög - gyökér; kör - szár; háromszög - levél.

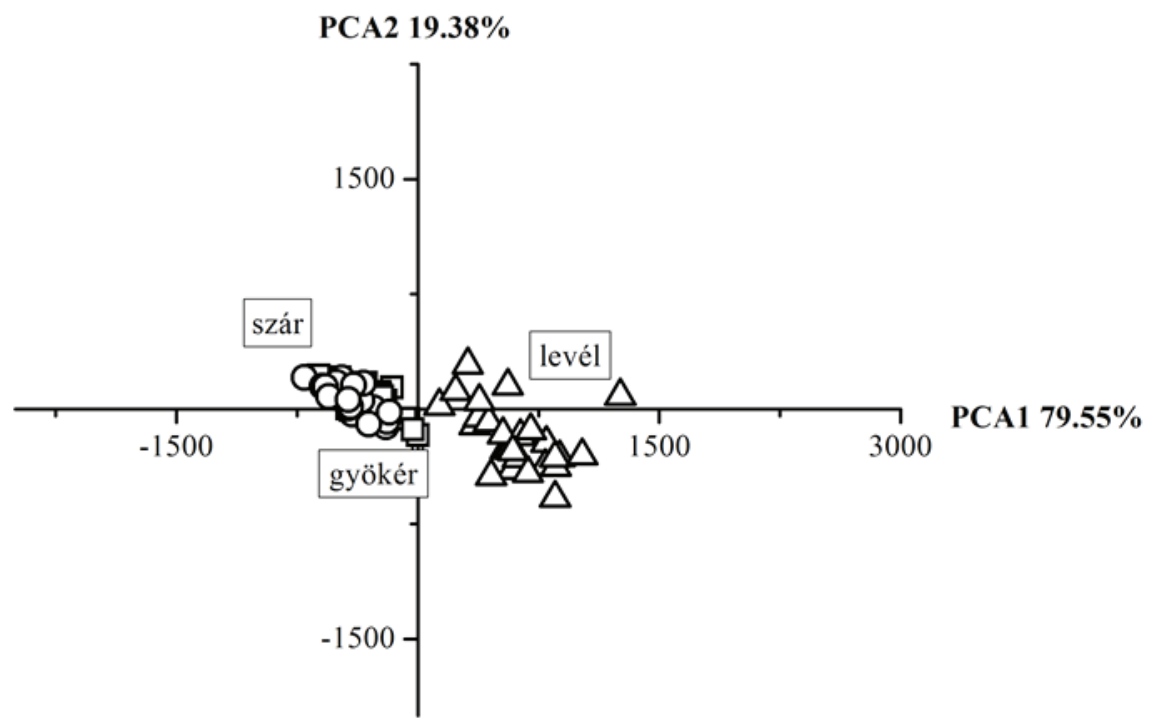

2. ábra: A kaporlevelü ebszékfü egyedek növényi szerveiben mért elemkoncentrációk $\left(\mathrm{mg} \mathrm{kg}^{-1}\right)$ főkomponens-analízise. Jelölések: négyszög - gyökér; kör - szár; háromszög - levél. 
az $\mathrm{Al}, \mathrm{Ca}, \mathrm{Fe}, \mathrm{K}, \mathrm{Mg}, \mathrm{Mn}, \mathrm{Na}, \mathrm{Ba}$ és $\mathrm{Zn}$ esetén tapasztaltunk szignifikáns eltérést a növények fémkoncentrációja alapján.

A fehér libatop egyedek esetében megállapítottuk, hogy a $\mathrm{Ca}, \mathrm{K}, \mathrm{Mg}, \mathrm{Mn}, \mathrm{Sr}$ és $\mathrm{Zn}$ a levelekben szignifikánsan $(\mathrm{p}<0,05)$ nagyobb koncentrációban volt jelen, mint a gyökerekben és a szárban. A Fe és Cu esetében ugyanezen mintázatot csupán az erősen szennyezett 2-es területrészen sikerült megfigyelni. Az Al és Ba kapcsán a szárban találtuk szignifikánsan a legkisebb koncentrációkat. A Cd koncentrációja minden esetben a kimutatási határérték alatt $\left(0,01 \mathrm{mg} \mathrm{kg}^{-1}\right)$ volt.

A kaporlevelü ebszékfü egyedek növényi szervei esetében azt tapasztaltuk, hogy az $\mathrm{Al}, \mathrm{Ba}, \mathrm{Cr}$ és $\mathrm{Pb}$ koncentrációja a gyökerekben volt szignifikánsan ( $\mathrm{p}<$ $0,05)$ a legnagyobb. A Ca, K, Mg és Mn a levelekben halmozódott fel szignifikánsan a legnagyobb koncentrációban. A Fe, $\mathrm{Na}, \mathrm{Cu}, \mathrm{Ni}$ és Sr koncentrációja a szárban volt a legkisebb, viszont nem szignifikáns mértékben. A Zn valamennyi növényi szervben hasonló mértékben akkumulálódott. A Cd koncentrációja e faj esetében is kimutatási határérték alatti volt.

A talajminták és a fehér libatop növényi szerveinek fémkoncentrációja között a mérsékelten szennyezett 1 -es területrészen szignifikáns $(\mathrm{p}<0,05)$ korreláció nem mutatkozott. Az erősen szennyezett 2 -es területrészen szignifikáns negatív korreláció jelentkezett az Al $(r=-0,700, p=0,036), F e(r=-0,683, p=0,042)$ és $\mathrm{Pb}(\mathrm{r}=-0,798, \mathrm{p}=0,010)$ esetében. A mérsékelten szennyezett 3-as területrészen szignifikáns pozitív korrelációt igazoltunk a $\mathrm{Cr}(\mathrm{r}=0,733, \mathrm{p}=0,025)$ és $\mathrm{Ni}$ $(\mathrm{r}=0,733, \mathrm{p}=0,025)$, illetve szignifikáns negatív korrelációt az $\mathrm{Al}(\mathrm{r}=-0,783$, $\mathrm{p}=0,013), \mathrm{Mg}(\mathrm{r}=-0,717, \mathrm{p}=0,030)$ és $\mathrm{Ba}(\mathrm{r}=-0,731, \mathrm{p}=0,025)$ vizsgálatakor.

A talajminták és a kaporlevelü ebszékfü növényi szerveinek fémkoncentrációja között a mérsékelten szennyezett 1 -es területrészen szignifikáns $(\mathrm{p}<0,05)$ pozitív korrelációt találtunk a $\mathrm{Fe}(\mathrm{r}=0,683, \mathrm{p}=0,042)$ esetében. Az erősen szennyezett 2-es területrészen szignifikáns negatív korrelációt a $\mathrm{Ca}(\mathrm{r}=-0,717, \mathrm{p}=0,030)$ és $\mathrm{Cu}(\mathrm{r}=-0,883, \mathrm{p}=0,002)$, míg szignifikáns pozitív korrelációt a $\mathrm{Sr}(\mathrm{r}=0,733$, $\mathrm{p}=0,025)$ vizsgálatakor jeleztünk. A mérsékelten szennyezett 3-as területrészen szignifikáns negatív korrelációt találtunk az Al $(\mathrm{r}=-0,667, \mathrm{p}=0,050)$ esetében.

\section{Értékelés}

Munkánk során megállapítottuk, hogy a fehér libatop egyedek fémkoncentrációja általánosan kicsi volt. Vizsgálati területünkhöz hasonló talajbéli Cd-koncentráció mellett Parisien et al. (2015) 0,7-4,4 mg kg-1 fémkoncentrációkat jeleztek, ellentétben az általunk tapasztalt kimutatási határérték alatti koncentrációkkal. A $\mathrm{Fe}, \mathrm{Mn}, \mathrm{Cr}, \mathrm{Cu}, \mathrm{Ni}, \mathrm{Pb}$ és $\mathrm{Zn}$ ugyancsak vizsgálatunkhoz hasonló talajkoncent- 


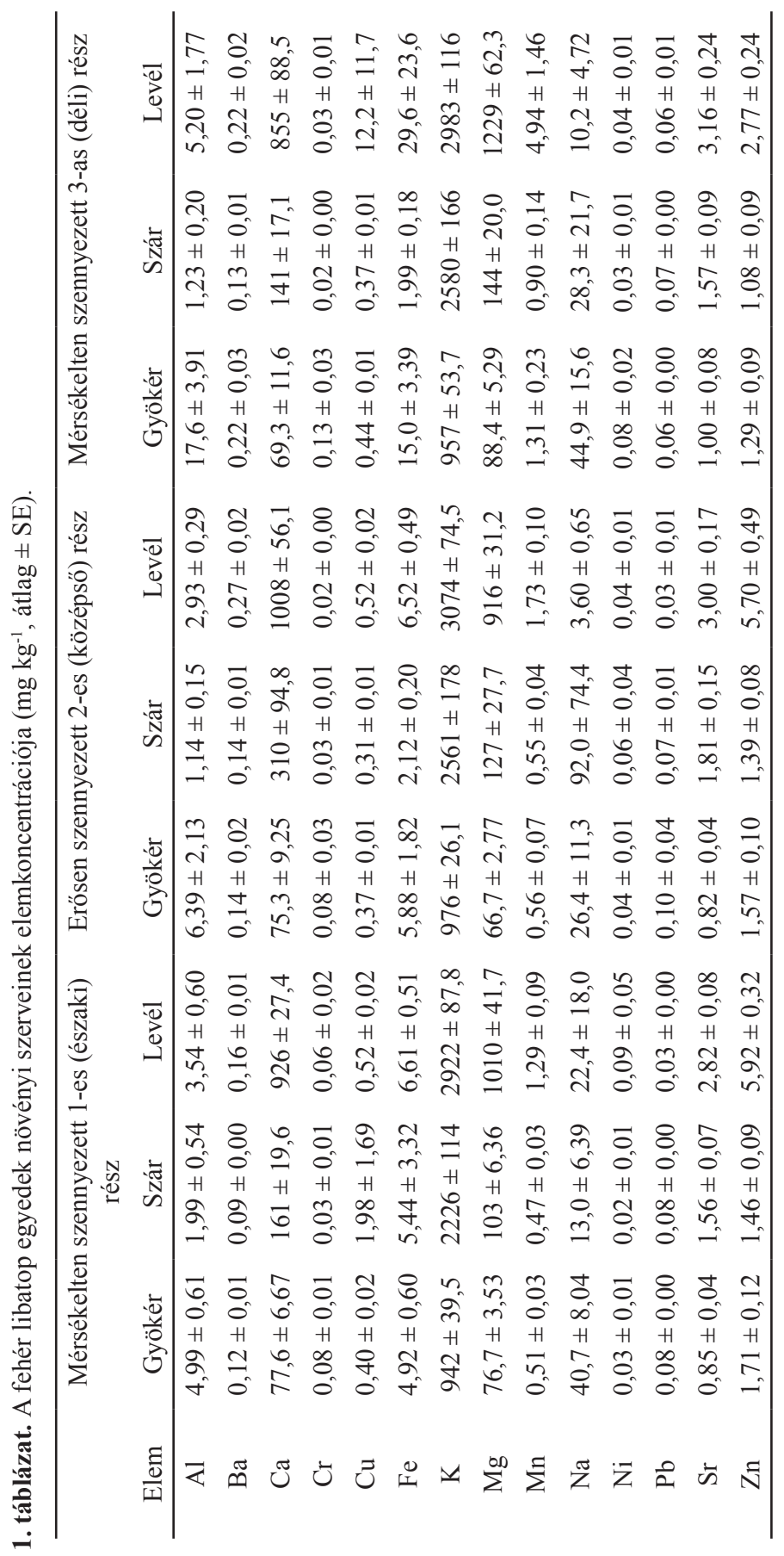




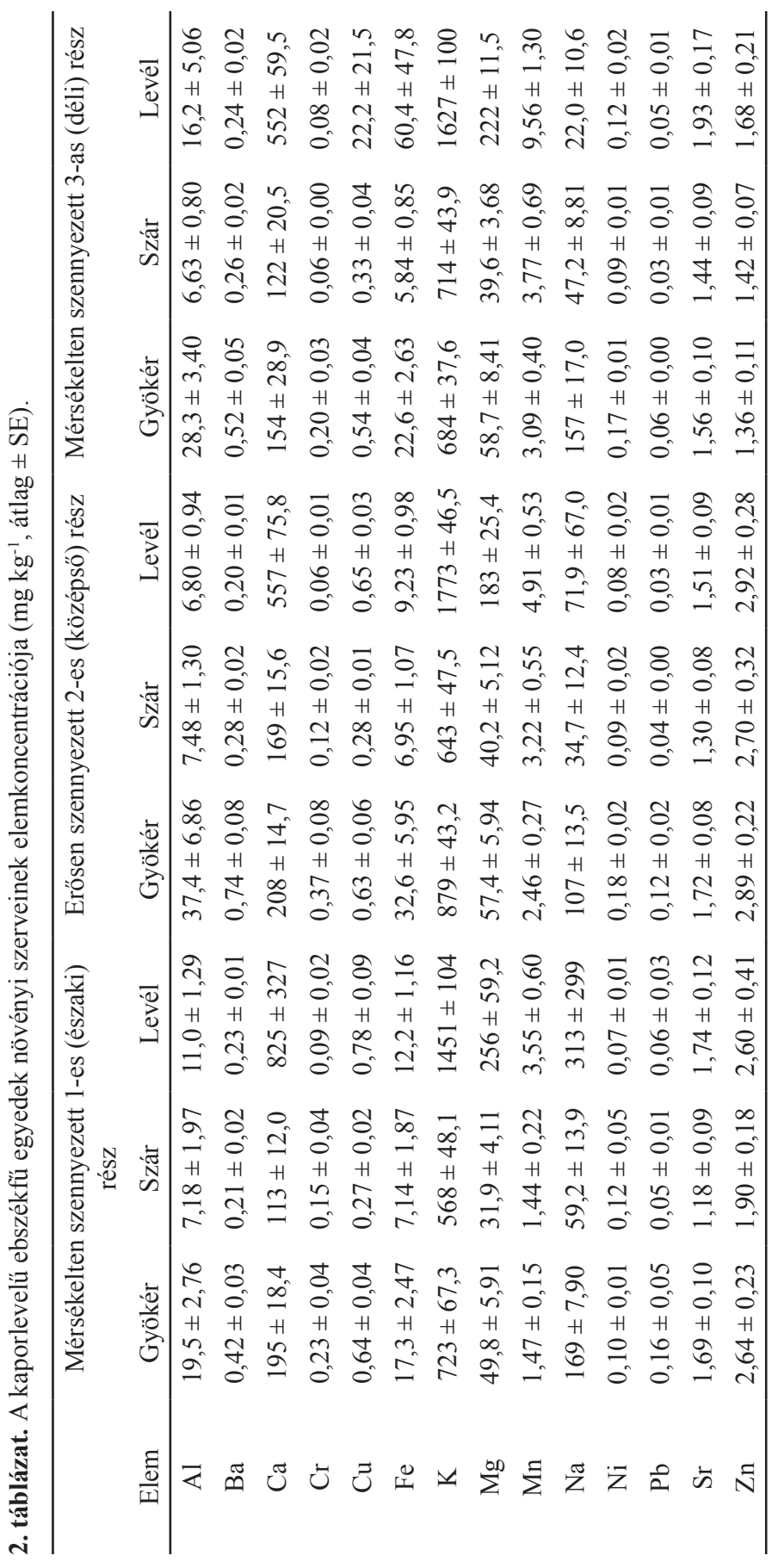


rációi mellett Gupta \& Sinha (2007) nagyobb koncentrációkat tapasztaltak a faj növényi szerveiben, mint azt eredményeink mutatják. Megjegyzendő, hogy hozzánk hasonlóan szintén a levelekben mérték a Fe, Cr, Ni és Pb koncentrációjának maximumát. Nouri et al. (2009) szintén az általunk tapasztalt koncentrációktól nagyobb Fe, Mn, Cu és Zn koncentrációkat figyeltek meg. Malik et al. (2010) a fehér libatop esetében eredményeinkhez hasonló Pb koncentrációt találtak. Hozzánk hasonlóan, veteménybab (Phaseolus vulgaris L.) egyedeket vizsgálva Tůma et al. (2004) szintén a levelekben igazolták a Ca és Mg legnagyobb koncentrációját. A kutatók ezt a Ca esetén a fém vakuólumokból történő lassú és korlátozott távozására, míg a Mg esetén a fém fotoszintézisben betöltött alapvető szerepére vezették vissza.

A kaporlevelü ebszékfü vizsgálatakor a fehér libatophoz hasonlóan kis akkumulációs potenciált jeleztünk. Geneva et al. (2014) orvosi székfü egyedekben az eredményeinktől nagyobb $\mathrm{Cu}, \mathrm{Pb}$ és $\mathrm{Zn}$ koncentrációkat mutattak ki. LydakisSimantiris et al. (2012) az orvosi székfü gyökereiben jelentősen nagyobb Ni és $\mathrm{Pb}$ akkumulációt figyeltek meg, mint a levelekben, eredményeinkkel ellentétben. Öt lágy szárú faj fémfelvételét elemezve Nwaedozie et al. (2015) a föld feletti növényi szervekben nagyobb Mn koncentrációt figyeltek meg, mint a gyökerekben, mely az általunk tapasztaltakkal megegyezik. A munkánk során igazolt nagy gyökérbéli Al koncentrációt lágyszárúak esetén Gordon \& Jackson (2000) is bizonyították, melyet a sürü hajszálgyökér-hálózattal magyaráztak. Sharma \& Sharma (2013) különböző fafajokat vizsgálva szintén a leveleket találták a fő K raktározó növényi szervnek.

A fehér libatop fémkoncentrációjának talajbéli értékekkel való összefüggésének vizsgálata szignifikáns negatív korrelációt igazolt az Al, Fe, Mg, Ba és Pb esetében. Eredményeinkkel ellentétben Galfati et al. (2011) rokon fajoknál a talajjal összevetve szignifikáns pozitív korrelációt igazoltak a $\mathrm{Cd}, \mathrm{Cu}, \mathrm{Ni}$ és $\mathrm{Zn}$ kapcsán. Tizenhárom növényfajt, köztük a fehér libatopot vizsgálva Liang et al. (2016) eredményeinkkel ellentétben szintén szignifikáns pozitív korrelációt tapasztaltak a Cd, Cu, Pb és Zn esetében. A Cr vizsgálatakor Samantaray et al. (2001) szignifikáns pozitív korrelációt találtak a talaj és négy fafaj fémkoncentrációja között.

A kaporlevelü ebszékfü növényi szerveinek vizsgálata során szignifikáns negatív korrelációt az $\mathrm{Al}, \mathrm{Ca}$ és $\mathrm{Cu}$, míg szignifikáns pozitív korrelációt a Fe és $\mathrm{Sr}$ mutatott. Lydakis-Simantiris et al. (2012) megfigyelték, hogy növekvő talajbéli $\mathrm{Cd}, \mathrm{Ni}$ és $\mathrm{Pb}$ koncentráció hatására az orvosi székfü egyedek növényi szerveinek fémkoncentrációja is emelkedett. Grejtovský et al. (2006) ugyanezen faj kapcsán, a $\mathrm{Zn}$ esetében figyeltek meg hasonló trendet. Eredményeink ezzel szemben azt mutatták, hogy a fémek talajbéli koncentrációjának csekély hatása van a növények által felvett koncentrációkra. Nouri et al. (2009) és Yoon et al. (2006) szá- 
mos különböző növényfaj vizsgálatakor az eredményeinket alátámasztó gyenge korrelációkról számoltak be.

Összefoglalva megállapíthatjuk, hogy a fehér libatop és a kaporlevelü ebszékfü egyaránt alkalmas lehet fémekkel szennyezett talajok környezeti kockázatának csökkentésére a toxikus elemek fitoakkumulációjával. A talajban és a növényi szervekben található fémkoncentrációk között több esetben is szignifikáns korrelációt tapasztaltunk. A két faj fitoextrakciós célú alkalmazását fóként mérsékelten szennyezett talajokon javasoljuk, mely során valamennyi növényi szerv betakarítására (beleértve a növényen és a talajon lévő leveleket is) nagy hangsúlyt kell fektetni.

Köszönetnyilvánítás - Munkánk megvalósulását a „Nemzet Fiatal Tehetségeiért Ösztöndíj” címü, NTP-NFTÖ-17-B kódjelü pályázat támogatta.

\section{Irodalomjegyzék}

Applequist, W. 1. (2002): A reassessment of the nomenclature of Matricaria L. and Tripleurospermum Sch. Bip. (Asteraceae). - Taxon 51: 757-761. doi: https://doi.org/10.2307/1555032

Armendaríz, M. D. R., Abellan, T. R., Gonzalez-Weller, D., Gonzalez, G. L., Fernandez, A. J. G. \& de la Torre, A. H. (2014): Metals (Al, Mn, Sr, Cd and Pb) in phytopharmaceuticals (Matricaria recutita, Tilia officinalis and Salvia officinalis). - Toxicol. Lett. 229: S182. doi: https://doi. org/10.1016/j.toxlet.2014.06.621

Bandiera, M., Dal Cortivo, C., Barion, G., Mosca, G. \& Vamerali, T. (2016): Phytoremediation opportunities with alimurgic species in metal-contaminated environments. - Sustainability-Basel. 8: 357 . doi: https://doi.org/10.3390/su8040357

Bhargava, A., Shukla, S., Srivastava, J., Singh, N. \& Ohri, D. (2008): Chenopodium: a prospective plant for phytoextraction. - Acta Physiol. Plant. 30: 111-120. doi: https://doi.org/10.1007/ s11738-007-0097-3

Dousset, S., Morel, J. L., Jacobson, A. \& Bitton, G. (2001): Copper binding capacity of root exudates of cultivated plants and associated weeds. - Biol. Fert. Soils. 34: 230-234. doi: https://doi. org/10.1007/s003740100404

Galfati, I., Bilal, E., Béji Sassi, A., Abdallah, H. \& Zaïer, A. (2011): Accumulation of heavy metals in native plants growing near the phosphate treatment industry, Tunisia. - Carpath. J. Earth Env. 6: $85-100$.

Geneva, M., Markovska, Y., Todorov, I. \& Stancheva, I. (2014): Accumulation of Cd, Pb, Zn and antioxidant response in chamomile (Matricaria recutita L.) grown on industrially polluted soil. - Genet. Plant Physiol. 4: 131-139.

Gordon, W. S. \& Jackson, R. B. (2000): Nutrient concentrations in fine roots. - Ecology 81: 275280. doi: https://doi.org/10.1890/0012-9658(2000)081[0275:NCIFR]2.0.CO;2

Grejtovský, A., Markušová, K. \& Eliašová, A. (2006): The response of chamomile (Matricaria chamomilla L.) plants to soil zinc supply. - Plant Soil Environ. 52: 1-7.

Gupta, A. K. \& Sinha, S. (2007): Phytoextraction capacity of the Chenopodium album L. grown on soil amended with tannery sludge. - Bioresource Technol. 98: 442-446. doi: https://doi. org/10.1016/j.biortech.2006.01.015 
Hoefer, C., Santner, J., Puschenreiter, M. \& Wenzel, W. W. (2015): Localized metal solubilization in the rhizosphere of Salix smithiana upon sulfur application. - Envir. Sci. Tech. 49: 4522-4529. doi: https://doi.org/10.1021/es505758j

Hu, R., Sun, K., Su, X., Pan, Y. X., Zhang, Y. F. \& Wang, X. P. (2012): Physiological responses and tolerance mechanisms to $\mathrm{Pb}$ in two xerophils: Salsola passerina Bunge and Chenopodium album L. - J. Hazard. Mater. 205-206: 131-138. doi: https://doi.org/10.1016/j.jhazmat.2011.12.051

Ishikawa, Y., Sato, S., Kurimoto, Y., Yamada, H., Hayakawa, A. \& Hidaka, S. (2014): Preliminary study of phytoremediation and biomass production by Salix species on abandoned farmland polluted with heavy metals. - J. Arid Land Stud. 23-24: 167-172.

Kacálková, L., Tlustoš, P. \& Száková, J. (2015): Phytoextraction of risk elements by willow and poplar trees. - Int. J. Phytoremediat. 17: 414-421. doi: https://doi.org/10.1080/15226514.2014 .910171

Kay, Q. O. N. (1994): Tripleurospermum inodorum (L.) Schultz Bip. - J. Ecol. 82: 681-697. doi: https://doi.org/10.2307/2261275

Liang, S. X., Gao, N., Li, Z. C., Shen, S. G. \& Li, J. (2016): Investigation of correlativity between heavy metals concentration in indigenous plants and combined pollution soils. - J. Chem. Ecol. 32: 872-883. doi: https://doi.org/10.1080/02757540.2016.1203909

Lydakis-Simantiris, N., Skoula, M., Fabian, M. \& Naxakis, G. (2012): Cultivation of medicinal and aromatic plants in heavy metal-contaminated soil - Exploitation with caution. 3rd International Conference on Industrial and Hazardous Waste Management, Crete, September 2012.

Mahar, A., Wang, P., Ali, A., Awasthi, M. K., Lahori, A. H., Wang, Q., Li, R. \& Zhang, Z. (2016): Challenges and opportunities in the phytoremediation of heavy metals contaminated soils: A review. - Ecotox. Environ. Safe. 126: 111-121. doi: https://doi.org/10.1016/j.ecoenv.2015.12.023

Malik, R. N., Husain, S. Z. \& Nazir, I. (2010): Heavy metal contamination and accumulation in soil and wild plant species from industrial area of Islamabad, Pakistan. - Pak. J. Bot. 42: 291-301.

Nouri, J., Khorasani, N., Lorestani, B., Karami, M., Hassani, A. H. \& Yousefi, N. (2009): Accumulation of heavy metals in soil and uptake by plant species with phytoremediation potential. - Environ. Earth Sci. 59: 315-323. doi: https://doi.org/10.1007/s12665-009-0028-2

Nwaedozie, G. C., Mohammed, Y., Faruruwa, D. M., Nwaedozie, J. M. \& Esekhagbe, R. O. (2015): Evaluation of accumulation ability for $\mathrm{Pb}, \mathrm{Cr}, \mathrm{Ni}$, and $\mathrm{Mn}$ in native plants growing on a contaminated air force shooting range, Kaduna. - Glob. J. Sci. Front. Res. B. 15.

Parisien, M. A., Rutter, A. \& Zeeb, B. A. (2015): Feasibility of using phytoextraction to remediate a compost-based soil contaminated with cadmium. - Int. J. Phytoremediat. 17: 1137-1143. doi: https://doi.org/10.1080/15226514.2014.1003792

Samantaray, S., Rout, G. R. \& Das, P. (2001): Heavy metal and nutrient concentration in soil and plants growing on a metalliferous chromite minespoil. - Environ. Technol. 22: 1147-1154. doi: https://doi.org/10.1080/09593332208618204

Samatadze, T. E., Amosova, A. V., Suslina, S. N., Zagumennikova, T. N., Mel'nikova, N. V., Bykov, V. A., Zelenin, A. V. \& Muravenko, O. V. (2014): Comparative cytogenetic study of the tetraploid Matricaria chamomilla L. and Matricaria inodora L. - Biology Bull. 41: 109-117. doi: https://doi.org/10.1134/S1062359013060125

Sharma, B. \& Sharma, K. (2013): Nutrient accumulation in various plant parts of dominant tree species of three different localities. - Pak. J. Biol. Sci. 15-16: 965-968.

Simon, E., Baranyai, E., Braun, M., Cserháti, Cs., Fábián, I. \& Tóthmérész, B. (2014): Elemental concentrations in deposited dust on leaves along an urbanization gradient. - Sci. Total Environ. 490: 514-520. doi: https://doi.org/ 10.1016/j.scitotenv.2014.05.028

Simon, E., Braun, M., Vidic, A., Bogyó, D., Fábián, I. \& Tóthmérész, B. (2011): Air pollution assessment based on elemental concentration of leaves tissue and foliage dust along an urbaniza- 
tion gradient in Vienna. - Environ. Pollut. 159: 1229-1233. doi: https://doi.org/10.1016/j.envpol.2011.01.034

Simon, E., Harangi, S., Baranyai, E., Fábián, I. \& Tóthmérész, B. (2016): Influence of past industry and urbanization on elemental concentrations in deposited dust and tree leaf tissue. - Urban For. Urban Gree. 20: 12-19. doi: https://doi.org/10.1016/j.ufug.2016.07.017

Simon, E., Vidic, A., Braun, M., Fábián, I. \& Tóthmérész, B. (2013): Trace element concentrations in soils along urbanization gradients in the city of Wien, Austria. - Environ. Sci. Pollut. R. 20: 917-924. doi: https://doi.org/10.1007/s11356-012-1091-x

Stanojkovic-Sebic, A., Pivic, R., Josic, D., Dinic, Z. \& Stanojkovic, A. (2015): Heavy metals content in selected medicinal plants commonly used as components for herbal formulations. - Tar. Bil. Der. 21: 317-325. doi: https://doi.org/10.1501/Tarimbil 0000001334

Tözsér, D., Magura, T. \& Simon, E. (2017): Heavy metal uptake by plant parts of willow species: A meta-analysis. - J. Hazard. Mater. 336: 101-109. doi: https://doi.org/10.1016/j.jhazmat.2017.03.068

Tőzsér, D., Harangi, S., Baranyai, E., Lakatos, Gy., Fülöp, Z., Tóthmérész, B. \& Simon, E. (2018): Phytoextraction with Salix viminalis in a moderately to strongly contaminated area. - Environ. Sci. Pollut. R. 25: 3275-3290. doi: https://doi.org/10.1007/s11356-017-0699-2

Tůma, J., Skalický, M., Tůmová, L., Bláhová, P. \& Rosůlková, M. (2004): Potassium, magnesium and calcium content in individual parts of Phaseolus vulgaris L. plant as related to potassium and magnesium nutrition. - Plant Soil Environ. 50: 18-26.

Vangronsveld, J., Herzig, R., Weyens, N., Boulet, J., Adriaensen, K., Ruttens, A., Thewys, T., Vassilev, A., Meers, E., Nehnevajova, E., van der Lelie, D. \& Mench, M. (2009): Phytoremediation of contaminated soils and groundwater: lessons from the field. - Environ. Sci. Pollut. R. 16: 765-794. doi: https://doi.org/10.1007/s11356-009-0213-6

Yoon, J., Cao, X., Zhou, X. \& Ma, L. Q. (2006): Accumulation of $\mathrm{Pb}, \mathrm{Cu}$, and $\mathrm{Zn}$ in native plants growing on a contaminated Florida site. - Sci. Total Environ. 368: 456-464. doi: https://doi. org/10.1016/j.scitotenv.2006.01.016

Zimmer, D., Baum, C., Leinweber, P., Hrynkiewicz, K. \& Meissner, R. (2009): Associated bacteria increase the phytoextraction of cadmium and zinc from a metal-contaminated soil by mycorrhizal willows. - Int. J. Phytoremediat. 11: 200-213. doi: https://doi.org/10.1080/15226510802378483 


\title{
Testing of metal accumulation of weeds in contaminated areas
}

\author{
Dávid Tőzsér \\ Department of Ecology, University of Debrecen \\ H-4032 Debrecen, Egyetem tér 1, Hungary \\ e-mail: tozser.david@windowslive.com
}

In the last few decades, the remediation of contaminated areas with weeds is getting more and more attention. In this work we studied the metal (Al, Ba, $\mathrm{Ca}, \mathrm{Cr}, \mathrm{Cu}, \mathrm{Fe}, \mathrm{K}, \mathrm{Mg}, \mathrm{Mn}, \mathrm{Na}, \mathrm{Ni}, \mathrm{Pb}, \mathrm{Sr}$ and $\mathrm{Zn}$ ) accumulation potential of Chenopodium album L. and Tripleurospermum inodorum (L.) Sch. Bip. based on the elemental concentration in roots, stem and leaves. Furthermore, we studied the correlation in metal concentration between soil and plant samples. Our results demonstrated that both species had low metal accumulation potential, compared to results from previous studies. Among plant parts of the species, we found leaves as the main metal accumulator organ. We indicated significant correlations in metal concentration between soil and plant species. We suggested that both $C$. album and $T$. inodorum can be successfully applied as metal accumulators, primarily due to high concentrations in leaves.

Keywords: metal, bioaccumulation, Chenopodium album, Tripleurospermum inodorum, weed species, plant organs 